\title{
Analisa Prioritas Faktor Kontinuitas Bisnis Industri Pelayaran Indonesia Menggunakan Analytic Network Process (ANP)
}

\author{
Ade Supandi( $^{(1)}$, Arief Daryanto(2), Bunasor Sanim ${ }^{(3)}$, Luky Adrianto(4) \\ $(1,2,3,4)$ Institut Pertanian Bogor, Indonesia \\ (1)2337pandi@gmail.com ${ }^{(2)}$ adaryant@mma.ipb.ac.id, \\ (3)bunasor@indo.net.id ${ }^{(4)}$ lukyadrianto@ipb.ac.id
}

DOI: https://doi.org/10.21107/rekayasa.v12i2.5541

\begin{abstract}
ABSTRAK
Kejadian ketidakamanan pelayaran di perairan Indonesia oleh Pembajakan dan Perampokan. Dalam insiden (2007-2018) di mana kerugian dilaporkan, kehilangan kargo adalah yang paling umum (33\%), diikuti oleh bagian-bagian mesin (15\%) dan barang tidak aman (4\%). Sementara dari 27 insiden yang dilaporkan pada 2018, tidak ada yang dicuri hanya dalam 10 insiden (37\%). Kerugiannya tentu tidak kecil dan mengancam kelangsungan bisnis perusahaan. Penelitian ini dilakukan dari Juni 2018 hingga Desember 2018. Penelitian dilakukan pada perusahaan pelayaran di Jakarta, badan keamanan laut, Direktorat Jenderal Perhubungan Laut dan TNI AL. Data dan fakta dikumpulkan dengan menggunakan kuesioner dan diuji dengan teknik analisis data Analytic Network Process (ANP). Hasilnya sebagai berikut: Fungsi Manajemen Risiko dengan prioritas 0,39092 adalah kriteria dengan prioritas tertinggi. Kemudian berturut-turut mempertahankan proses bisnis dengan prioritas 0,27899, Dokumentasi 0,18325 dan Pengawasan Manajemen dengan prioritas 0,14684. Dari hasil tersebut, kami dapat merekomendasikan bahwa faktor yang paling penting untuk kelangsungan bisnis industri pelayaran adalah Fungsi Manajemen Risiko.

Kata Kunci: Industri Perkapalan, Kontinuitas Bisnis, Analytic Network Process
\end{abstract}

\section{ABSTRACT}

\section{Priority Analysis of Indonesia's Delivery Industry Continuity Factors} Using Analytic Network Process (ANP)

The incidence of shipping insecurity in Indonesian waters by piracy and robbery. In incidents (2007-2018) where losses were reported, cargo loss was the most common (33\%), followed by engine parts (15\%) and unsafe goods (4\%). While of the 27 incidents reported in 2018, none were stolen in only 10 incidents (37\%). The loss is certainly not small and threatens the company's business continuity. This research was conducted from June 2018 to December 2018. The research was conducted on shipping companies in Jakarta, marine security agencies, the Directorate General of Sea Transportation and the Indonesian Navy. Data and facts were collected using a questionnaire and tested with the Analytic Network Process (ANP) data analysis techniques. The results are as follows: The Risk Management function with a priority of 0.39092 is the criteria with the highest priority. Then maintain business processes with priority 0.27899 , Documentation 0.18325 and Management Supervision with priority 0.14684 . From these results, we can recommend that the most important factor for the continuity of the shipping industry business is the Risk Management Function.

Keywords: Shipping Industry, Business Continuity, Analytic Network Process

\section{PENDAHULUAN}

\section{Latar Belakang}

Data dari Asosiasi Pemilik Kapal Nasional Indonesia (INSA), digabungkan dengan data dari Kementerian Perhubungan (2018), memiliki 3.918 perusahaan angkutan laut dan 1.600 perusahaan yang menjadi anggota INSA dengan $12.500 \mathrm{kapal}$, sementara jumlah kapal yang sah terdaftar di The Badan Klasifikasi Kapal Indonesia adalah 10.580 kapal, yang berarti $84,64 \%$. Kapal-kapal milik INSA dapat dikelompokkan menjadi beberapa jenis:

\footnotetext{
Article History:

Received: July, 12 nd 2019; Accepted: September, 29 2019

ISSN: 2502-5325 (Online) Terakreditasi Peringkat 3 oleh Kementerian Riset, Teknologi dan Pendidikan Tinggi (ARJUNA), berdasarkan Keputusan Direktur Jenderal Penguatan Riset dan Pengembangan No: 23/E/KPT/2019 tanggal 8 Agustus 2019
}

kapal kontainer, kapal kargo, kapal lepas pantai, kapal pengangkut penumpang, kendaraan bermotor dan RoRo, kapal kargo gas, kapal non-minyak, kapal kargo curah, kapal tarik \& tongkang dan kapal kargo cair.

Selanjutnya, dalam kegiatan pelayaran yang terjadi di Indonesia, pembajakan dan perompakan dalam beberapa tahun terakhir selalu terjadi. Data yang diterbitkan ReCAAP (Regional Cooperation Agreement on Combating Piracy and Armed Robbery

\section{Cite this as:}

Supandi, A. Daryanto, A. Sanim, B. \& Adrianto, L. (2019). Analisa Prioritas Faktor Kontinuitas Bisnis Industri Pelayaran Indonesia Menggunakan Analytic Network Process (ANP). Rekayasa, 12(2), 104-111. doi: https://doi.org/10.21107/rekayasa.v12i2.5541 (c) 2019 Ade Supandi, Arief Daryanto, Bunasor Sanim, Luky Adrianto 


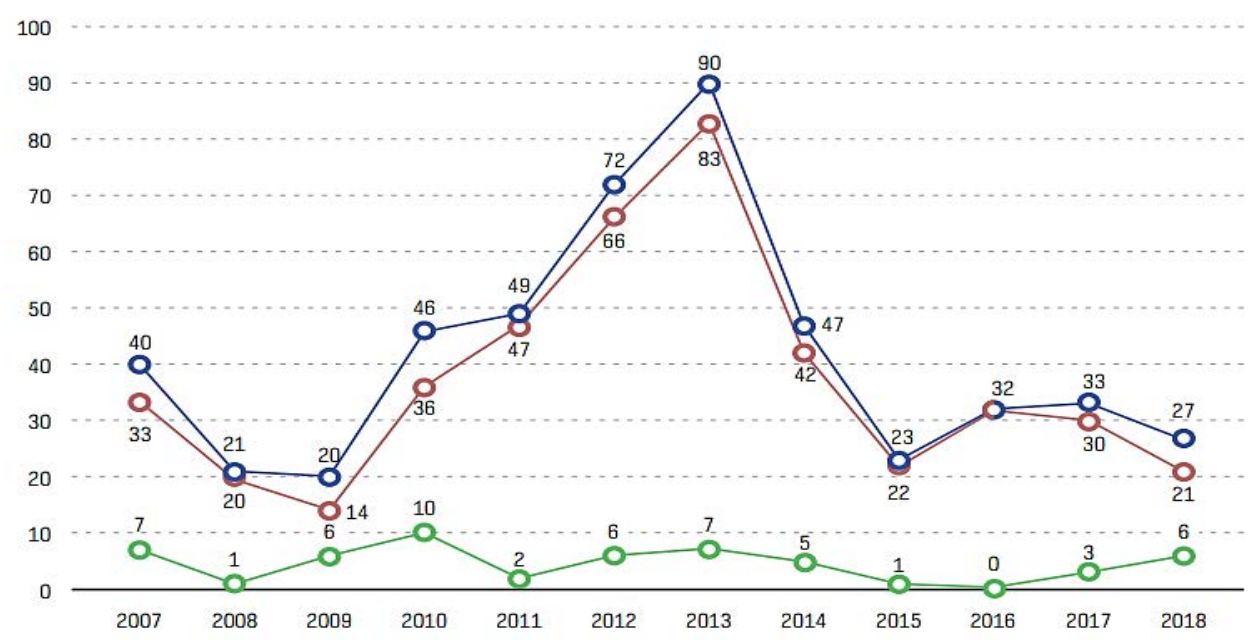

Gambar 1. Banyaknya insiden pembajakan dan perompakan bersenjata di Indonesia 2007 sampai dengan 2018 (total, aktual dan percobaan)

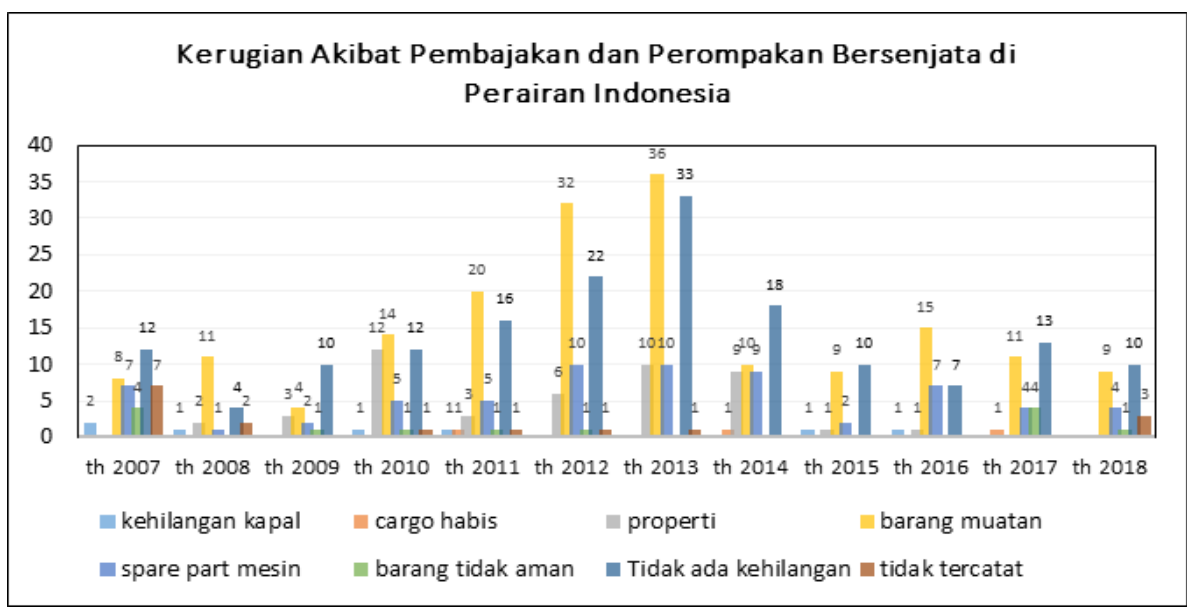

Gambar 2. Tipe Kerugian akibat pembajakan dan perompakan bersenjata di perairan Indonesia tahun 2007 sampai dengan 2018

against Ships in Asia) dalam Annual Report 2018 Piracy and Arm Robbery Against Ship Asia menunjukkan kerugian yang cukup besar, sebagai berikut.

Data menunjukkan bahwa masih ada ketidakamanan pelayaran di perairan Indonesia yang harus diantisipasi oleh perusahaan pelayaran. Sementara kerugian yang diderita, masih didasarkan pada data dari ReCAAP (Regional Cooperation Agreement on Combating Piracy and Armed Robbery against Ships in Asia) dalam Annual Report 2018 Piracy and Arm Robbery Against Ship Asia menunjukkan data percobaan, aktual dan total pembajakan dan perompakan bersenjata yang dilakukan terhadap kapal di perairan Indonesia mulai tahun 2007 sampai dengan 2018 dapat dilihat di gambar 2.

Dalam insiden di mana kerugian dilaporkan, kehilangan kargo adalah yang paling umum (33\%), diikuti oleh bagian-bagian mesin (15\%) dan barang tidak aman (4\%). Sementara dari 27 insiden yang dilaporkan pada 2018, tidak ada yang dicuri hanya dalam 10 insiden (37\%). Kerugiannya tentu tidak kecil dan mengancam kelangsungan bisnis perusahaan.

Lebih jauh, berdasarkan analisis Allianz Global Corporate \& Speciality (AGCS) terhadap hampir 15.000 klaim asuransi kewajiban maritim antara 2011 dan 2017 menunjukkan bahwa kesalahan manusia mencapai $75 \%$ dari nilai semua klaim yang dianalisis, setara dengan lebih dari \$1,6 miliar. Selanjutnya, kerusakan / kecelakaan alami mencapai $18 \%$, setara dengan \$0,384 miliar. Selanjutnya, secara rinci klaim asuransi secara keseluruhan dan penyebabnya disajikan dalam tabel 1 .

Dari total klaim asuransi, tentu saja, dapat diperkirakan berdasarkan data Review of Transports (RMT) pada tahun 2018 bahwa jumlah armada pedagang di dunia pada tanggal 1 Januari 2018 adalah 94.171 unit, dengan total tonase dari 1,92 miliar DWT dan Indonesia berada di peringkat ke-20 dengan total tonase $20 \mathrm{Jt}$ DWT untuk kapal 1.000 GT ke atas. Dengan perbandingan ini, dan berdasarkan data tentang kerugian akibat perompakan dan pembajakan pada Gambar 2 diperkirakan total klaim asu- 
Tabel 1. Klaim asuransi kewajiban maritim tahun 2011 - 2017

\begin{tabular}{llcc}
\hline No & \multicolumn{1}{c}{ Penyebab } & Persentase & Kerugian (US\$) \\
\hline 1 & Kesalahan manusia & $75 \%$ & 1.600 miliar \\
2 & Sifat / kerusakan tidak disengaja & $18 \%$ & 0.384 miliar \\
3 & Bahaya alam & $1 \%$ & 0.021 miliar \\
4 & Kelalaian / pemeliharaan yang buruk & $<1 \%$ & $<0.021$ miliar \\
5 & Kegagalan untuk Memberikan Layanan & $<1 \%$ & $<0.021$ miliar \\
6 & Kesalahan manusia & $5 \%$ & 0.107 miliar \\
\hline & \multicolumn{1}{c}{ Total } & $100 \%$ & Hampir 2.115 miliar \\
\hline
\end{tabular}

Sumber: Safety and Shipping Review 2018: An annual review of trends and developments in shipping losses and safety

ransi maritim Indonesia mencapai US \$220 juta. Ini adalah nilai ekonomi yang secara makro dan mikro perlu menjadi perhatian untuk keamanan dan keselamatan pelayaran di Indonesia dan kelangsungan bisnis industri pelayaran.

Smith, W. (2016) menjelaskan bahwa perusahaan pelayaran sadar bahwa ada banyak pedoman peraturan yang diberikan kepada mereka terkait keselamatan dan keamanan kapal. Namun, memiliki Business Continuity Management System (BCMS) yang berjalan di tempat harus dilihat oleh perusahaan pelayaran sebagai komponen yang sama pentingnya untuk operasi berbasis pantai mereka. Untuk mempersiapkan diri menghadapi risiko gangguan, perusahaan pelayaran harus memenuhi persyaratan untuk mengimplementasikan rencana manajemen kelangsunganbisnis yang layak dan teruji. Semua gangguan keamanan dan keselamatan dapat merusak elemen-elemen utama yang perlu dilakukan oleh bisnis:

1. Orang - diperlukan untuk mengelola dan mengoperasikan perusahaan

2. Lokasi (jalur darat) - untuk menyediakan fasilitas kantor dan pergudangan

3. Teknologi informasi dan infrastruktur telekomunikasi

4. Informasi dan data bisnis (termasuk dokumen cetak / kertas)

5. Rantai pasokan - penyedia pihak ketiga termasuk pelabuhan, bongkar muat, katering, penyedia bunker, kontraktor, konsultan, vendor, dll.

6. Transportasi - untuk awak, kargo, dan logistik

7. Keuangan - untuk menyediakan likuiditas yang diperlukan untuk beroperasi.

Tidak tersedianya satu atau beberapa elemen kunci ini berpotensi menyebabkan seluruh perusahaan macet. Mengembangkan, menerapkan dan menanamkan kelangsungan bisnis ke dalam sistem manajemen perusahaan akan membantu mengurangi dampak gangguan pada praktik kerja dan pemberian layanan. Sistem Manajemen Kelangsungan Bisnis akan membantu perusahaan untuk meminimalkan risiko mereka dan kemungkinan mereka mengalami gangguan. Namun, jika yang terburuk terjadi, BCMS yang baik akan membantu pemuli- han yang efektif dan cepat setelah membantu melindungi operasi perusahaan. Sesuai dengan penelitian dari Hecht (2002) Bajgoric (2006), Bajgoric \& Moon (2009), British Standards Institution (2006), Castillo (2005), Swartz et al. (2003), Speight (2011) dan McAfee (2016) bahwa kelangsungan bisnis adalah prioritas pengawasan manajemen, fungsi manajemen risiko dan dokumentasi rencana dan dokumentasi dari proses mempertahankan bisnis. Kelangsungan bisnis industri perkapalan sangat dibutuhkan dalam pengembangan negara-negara maritim seperti Indonesia sehingga tentunya juga dapat berkontribusi terhadap keberlanjutan pembangunan nasional.

\section{Perumusan masalah}

Dari latar belakang di atas, masalah utama dapat diidentifikasi, yaitu: Manajemen keamanan maritim dalam industri pelayaran yang efektif adalah tantangan besar karena permintaan untuk lebih meningkatkan manajemen keamanan dengan harapan meningkatkan kelangsungan bisnis industri pelayaran. Berdasarkan latar belakang dan pokok permasalahan dari masalah di atas, masalah penelitian dapat dirumuskan sebagai pertanyaan penelitian yaitu : bagaimana prioritas pengawasan manajemen, fungsi manajemen risiko, dokumentasi rencana dan proses mempertahankan bisnis pada kelangsungan bisnis perusahaan pelayaran?

\section{KAJIAN PUSTAKA}

\section{Kelangsungan Bisnis Industri Pelayaran}

Hecht (2002) mendefinisikan kelangsungan bisnis sebagai "about ensuring that critical business functions can continue" atau tentang memastikan bahwa fungsi bisnis yang penting dapat berlanjut. Selanjutnya Bajgoric (2006) menjelaskan hal itu "The term 'Business Continuity' has been introduced in order to emphasize the ability of a business to continue with its operations event if some sort of disaster occurs." (P. 450) atau kemampuan bisnis untuk melanjutkan operasi bahkan jika jenis bencana tertentu terjadi. Berdasarkan teori Hetcht, perusahaan yang memiliki kelangsungan bisnis adalah perusahaan dengan kemampuan tinggi untuk menangani kecelakaan dan bencana yang memungkinkan ker- 
ugian besar perusahaan, tetapi perusahaan tersebut mampu bangkit dan bertahan.

Definisi lain oleh Bajgoric \& Moon (2009) adalah "The term, 'business continuity' (business continuance, business resilience) refers to the ability of a business to continue with its operations even if some sort of failure or disaster occurs." (P 74), atau kemampuan bisnis untuk melanjutkan operasi bahkan jika beberapa kegagalan atau bencana terjadi. Definisi Bajgoric dan Moon menjelaskan bahwa meskipun ada beberapa peristiwa.

Definisi Hecht (2002), Bajgoric (2006), Bajgoric \& Moon (2009) sangat kompatibel dengan definisi Castillo (2005) yang secara eksplisit menggambarkan kelangsungan bisnis sebagai kemampuan untuk mempertahankan aliran pendapatan melalui krisis atau "the ability to retain a revenue stream through a crisis".

Beberapa definisi berikut menjelaskan secara manajemen perusahaan terkait dengan kemampuannya untuk memastikan kelangsungan bisnisnya. Definisi ini dikembangkan oleh Swartz et al (2003), British Standards Institution (2006), Andre, K. (2009), Speight (2011), dan McAfee (2016).

Swartz et al. (2003) mendefinisikan kelangsungan bisnis sebagai proses manajemen yang mengidentifikasi ancaman internal dan eksternal organisasi, dan proses mana yang efektif dan efektif sambil memungkinkan keunggulan kompetitif dan integritas sistem nilai "(hal. 66), atau proses manajemen yang mengidentifikasi kemampuan organisasi terhadap ancaman internal dan eksternal, dan yang mensintesis aset keras dan lunak untuk memberikan pencegahan dan pemulihan yang efektif sambil memungkinkan keunggulan kompetitif dan integritas sistem nilai.

Definisi lain dari kelangsungan bisnis perusahaan oleh British Standards Institution (2006) sebagai "kemampuan strategis dan taktis organisasi untuk merencanakan dan merespons insiden dan gangguan bisnis dalam rangka melanjutkan operasi bisnis dan tingkat yang telah ditentukan sebelumnya yang dapat diterima" ( $h .1$ ) atau kemampuan strategis dan taktis organisasi untuk merencanakan dan menanggapi insiden dan gangguan bisnis untuk melanjutkan operasi bisnis pada tingkat pra-definisi yang dapat diterima.

Definisi selanjutnya oleh Andre, K. (2009) menyatakan bahwa kelangsungan bisnis sebagai upaya untuk meminimalkan gangguan atau gangguan bisnis yang disebabkan oleh berbagai kemungkinan. Ketika ini terjadi, pemulihan bisnis dan dimulainya kembali harus dicapai mungkin. Intinya, bisnis harus berlanjut.

Speight (2011) mendefinisikan kelangsungan bisnis, yaitu "proses manajemen yang mengidentifikasi faktor-faktor potensial yang mengancam organisasi dan menyediakan kerangka kerja untuk membangun ketahanan dan kemampuan untuk respons yang efektif." (P. 529) atau proses manajemen yang mengidentifikasi faktor-faktor yang berpotensi mengancam organisasi dan menyediakan kerangka kerja untuk membangun ketahanan dan kemampuan untuk merespons secara efektif.

Definisi lain oleh McAfee (2016) yaitu:

"The processes involved in managing exposure to internal and external threats that can disrupt the availability of an organization's business operations. This involves the management oversight, risk management functions and the documentation of plans and processes to maintain business in the event of a disruption of business"

Berdasarkan berbagai definisi di atas, dalam penelitian ini kontinuitas bisnis dapat dirumuskan sebagai proses mengelola paparan terhadap ancaman internal dan eksternal yang dapat mengganggu ketersediaan operasi bisnis perusahaan. Ini melibatkan pengawasan manajemen, fungsi manajemen risiko dan dokumentasi rencana dan proses untuk mempertahankan bisnis jika terjadi gangguan bisnis.

Dalam penelitian ini, berdasarkan Hecht (2002) Bajgoric (2006), Bajgoric \& Moon (2009), British Standards Institution (2006), Castillo (2005), Swartz et al. (2003), Andre, K. (2009), Speight (2011), dan McAfee (2016) dan Alma, B (2017) faktor dan atribut pengawasan manajemen, fungsi manajemen risiko dan dokumentasi rencana dan dokumentasi proses pemeliharaan bisnis pada kontinuitas bisnis dapat digambarkan pada gambar 3.

\section{METODE PENELITIAN}

\section{Desain penelitian}

Penelitian ini dilakukan dari Juni 2018 hingga Desember 2018. Selanjutnya, penelitian dilakukan pada perusahaan pelayaran di Jakarta, Badan Keamanan Laut, Direktorat Jenderal Perhubungan Laut dan TNI AL. Teknik pengambilan sampel menggunakan pilihan ahli, yaitu seseorang yang benar-benar memahami seluk beluk perusahaan pelayaran dan kegiatan pelayaran. Dalam studi ini subjek penelitian termasuk perusahaan pelayaran di Jakarta, agen keamanan laut, dan direktorat transportasi laut dan TNI AL. Selanjutnya, data dan fakta dari kuesioner yang dikumpulkan akan diuji dengan teknik analisis data Analytic Network Process (ANP).

\section{Subjek Penelitian}

Penelitian ini dilakukan dengan subjek penelitian ahli sesuai dengan model expert choice, yaitu memilih orang yang dianggap memiliki informasi yang cukup dan memahami masalah, terutama industri perkapalan dan kegiatan pelayaran. Dalam penelitian ini, total sampel 45 orang dari semua pemangku kepentingan dapat digunakan yang terkait erat dengan industri pelayaran yang diwakili, yaitu: 30 ahli dari perusahaan pelayaran; 
108 | Supandi, A. dkk., Analisa Prioritas Faktor Kontinuitas Bisnis Industri Pelayaran Indonesia...

Hecht (2002) Bajgoric (2006), Bajgoric \& Moon (2009), British Standards Institution (2006), Castillo (2005), Swartz et al.

(2003), Andre, K. (2009), Speight (2011), dan McAfee (2016)

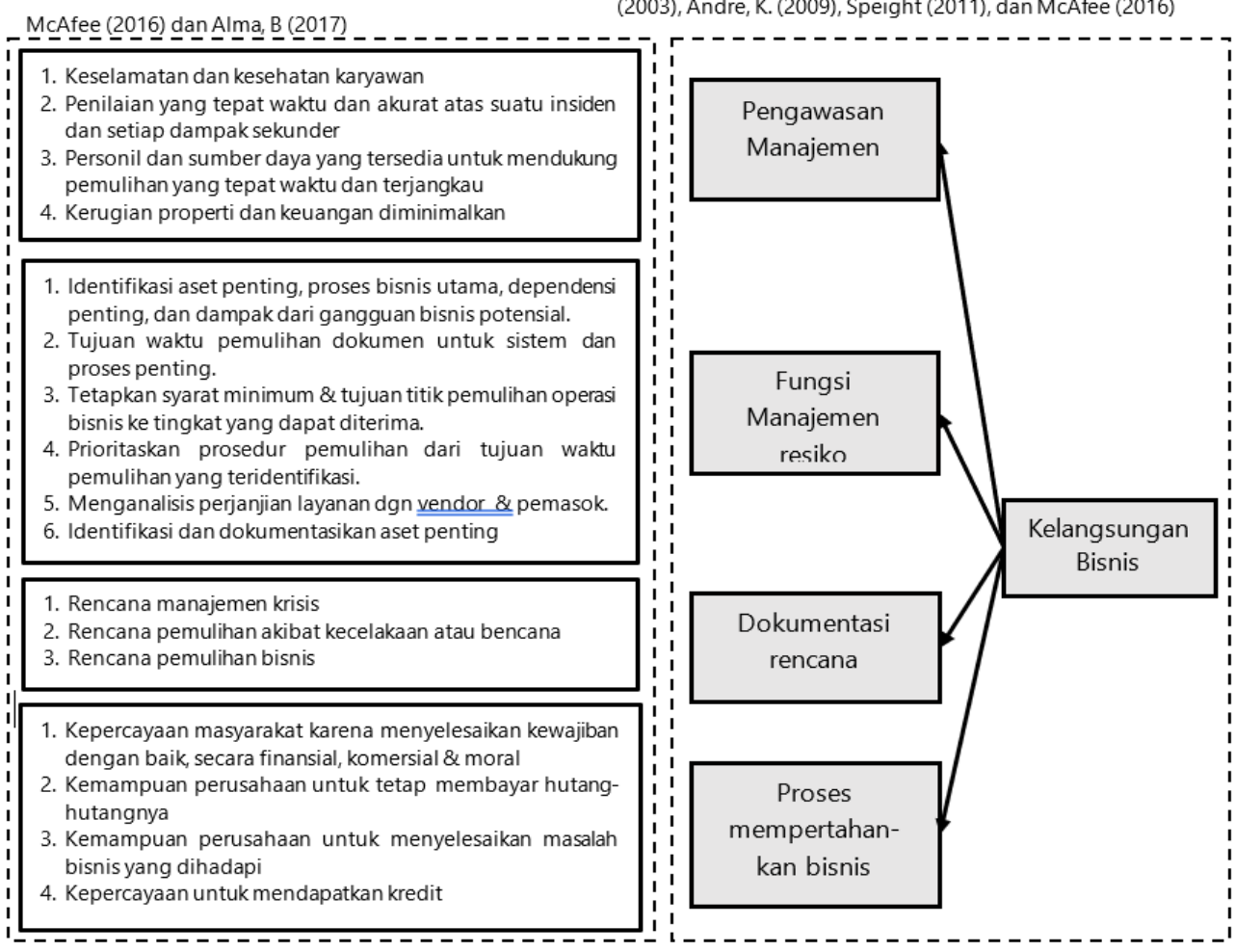

Gambar 3. Prioritas atribut terhadap Kelangsungan bisnis

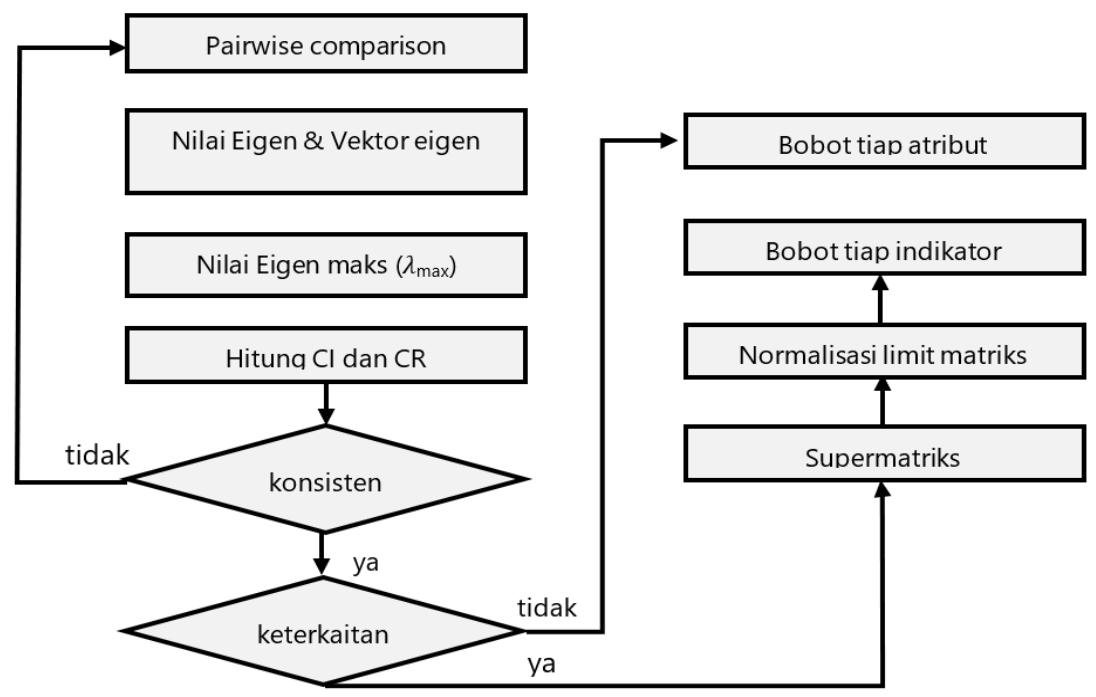

Gambar 4. Algoritma penyelesaian masalah dengan ANP

5 pejabat yang sesuai dengan tugas tanggung jawabnya dari Direktorat Jenderal Perhubungan Laut; 5 pejabat yang sejalan dengan tugas mereka dari Badan Keamanan Maritim; dan 5 pejabat yang sesuai dengan tugas tanggung jawab mereka dari TNI AL.

\section{Metode analisis data}

Pengumpulan data dilakukan dengan mengisi kuesioner yang disiapkan. Setiap responden yang terpilih mendapat surat lamaran untuk mengisi kuesioner dan meninggalkan kuesioner untuk di- isi. Setelah mengumpulkan data, langkah selanjutnya adalah menganalisis data menggunakan ANP. Seperti yang dilakukan oleh Saptono dan Angraini (2014). Langkah-langkah pemecahan masalah dengan ANP, dikompilasi dengan algoritma perhitungan yang divisualisasikan pada gambar 4 .

\section{ANALISIS DAN PEMBAHASAN}

\section{Hasil Pemodelan}

Pemodelan dilakukan berdasarkan pada model hipotetis dengan Analysis Network Process (ANP). 


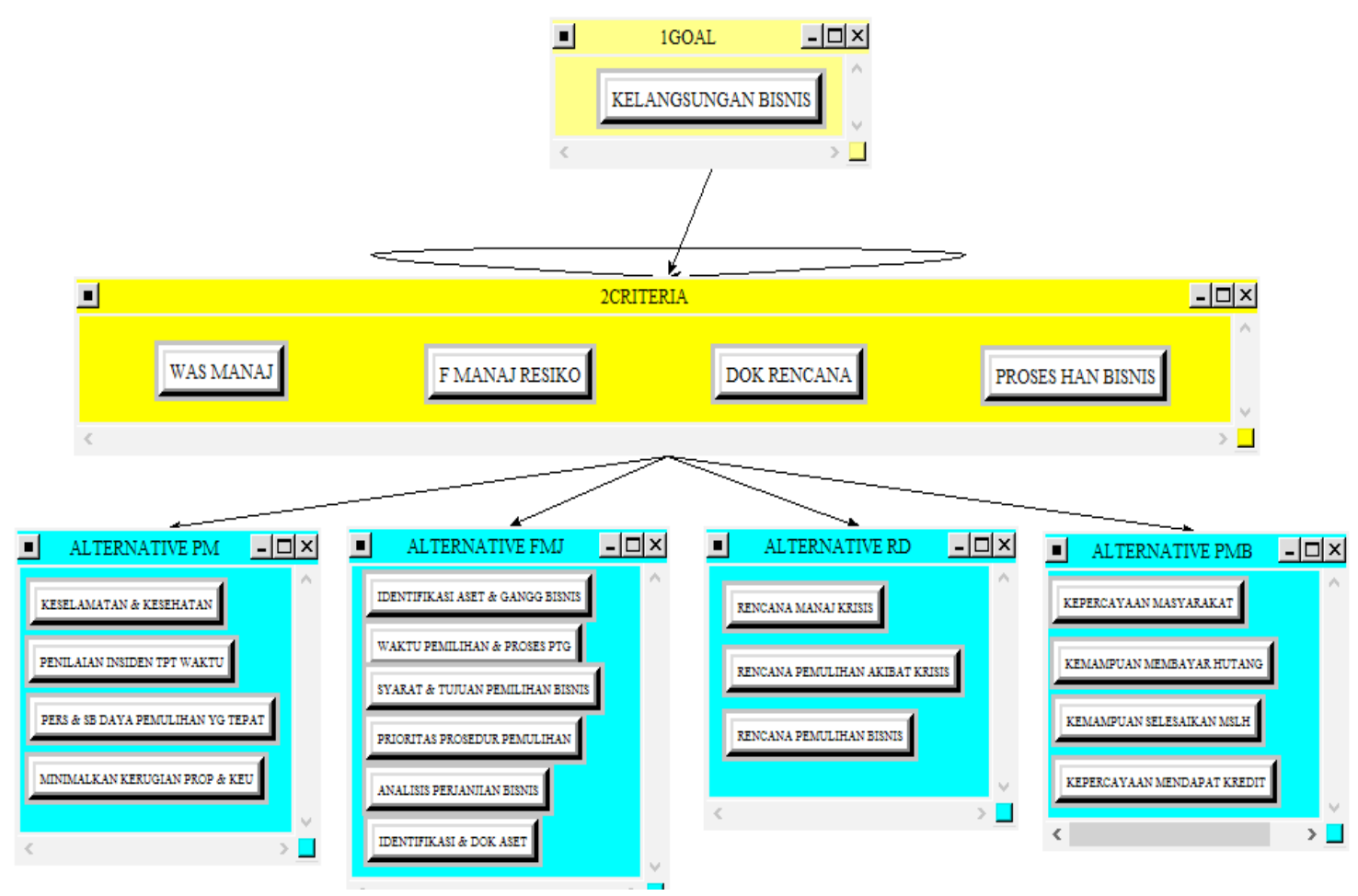

Gambar 5. Model ANP pada kelangsungan bisnis industri pelayaran

Dalam model ini dengan ANP, kriteria prioritas dan hubungan antar kriteria dipertimbangkan, prioritas alternatif untuk setiap kriteria dan hubungan antar alternatif. Model keseluruhan disusun seperti pada gambar 5.

\section{Prioritas KelangsunganBisnis}

Dari perhitungan super matrix tertimbang, hasil prioritas kriteria untuk kelangsungan bisnis diperoleh sebagai berikut:

\begin{tabular}{ll}
\hline \multicolumn{1}{c}{ Alternatif } & $\begin{array}{c}\text { Normalisasi } \\
\text { prioritas }\end{array}$ \\
\hline Dokumentasi Rencana & 0.18325 \\
Fungsi Manajemen Risiko & 0.39092 \\
Proses mempertahankan bisnis & 0.27899 \\
Pengawasan Manajemen & 0.14684 \\
\hline
\end{tabular}

Alternatif prioritas dalam kriteria pada kluster Pengawasan Manajemen

\begin{tabular}{|c|c|}
\hline Alternatif & $\begin{array}{c}\text { Normalisasi } \\
\text { prioritas }\end{array}$ \\
\hline Kesehatan \& Keselamatan & 0.28647 \\
\hline $\begin{array}{l}\text { Minimalkan Kerugian Properti \& } \\
\text { Keuangan }\end{array}$ & 0.28647 \\
\hline Penilaian Insiden yang Tepat Waktu & 0.21728 \\
\hline $\begin{array}{l}\text { Personil \& Sumber Daya Pemulihan } \\
\text { yang Tepat }\end{array}$ & 0.20977 \\
\hline
\end{tabular}

Alternatif prioritas untuk kriteria kluster Fungsi Manajemen Risiko

\begin{tabular}{ll}
\hline \multicolumn{1}{c}{ Alternatif } & \multicolumn{1}{c}{$\begin{array}{c}\text { Normalisasi } \\
\text { prioritas }\end{array}$} \\
\hline Analisis Kesepakatan Bisnis & 0.16541 \\
Identifikasi \& Dokumentasi Aset & 0.14538 \\
$\begin{array}{l}\text { Identifikasi Aset \& Gangguan } \\
\text { Bisnis }\end{array}$ & 0.20269 \\
Prioritas Prosedur Pemulihan & 0.2292 \\
Syarat \& Tujuan Seleksi Bisnis & 0.13989 \\
$\begin{array}{l}\text { Pemulihan Penting \& Waktu } \\
\text { Proses }\end{array}$ & 0.11744 \\
\hline
\end{tabular}

Alternatif prioritas untuk kriteria pada kluster Dokumentasi Risiko

\begin{tabular}{|c|c|}
\hline Alternatif & $\begin{array}{c}\text { Normalisasi } \\
\text { prioritas }\end{array}$ \\
\hline Rencana Manajemen Krisis & 0.25993 \\
\hline Rencana Pemulihan Karena Krisis & 0.4126 \\
\hline Rencana Pemulihan Bisnis & 0.32748 \\
\hline \multicolumn{2}{|c|}{$\begin{array}{l}\text { Alternatif prioritas dalam kriteria kluster memper } \\
\text { tahankan bisnis }\end{array}$} \\
\hline Alternatif & $\begin{array}{l}\text { Normalisasi } \\
\text { prioritas }\end{array}$ \\
\hline Kemampuan membayar hutang & 0.17602 \\
\hline Kemampuan mengatasi masalah & 0.29754 \\
\hline Kepercayaan komunitas & 0.24545 \\
\hline Kepercayaan memperoleh kredit & 0.28098 \\
\hline
\end{tabular}


110 | Supandi, A. dkk., Analisa Prioritas Faktor Kontinuitas Bisnis Industri Pelayaran Indonesia...

Dengan demikian, pada kelangsungan bisnis, Fungsi Manajemen Risiko dengan prioritas 0,39092 adalah kriteria dengan prioritas tertinggi. Kemudian berturut-turut mempertahankan proses bisnis dengan prioritas 0,27899, Paket Dokumentasi 0,18325 dan Pengawasan Manajemen dengan prioritas 0,14684 .

Berdasarkan urutan prioritas, kelangsunganbisnis sangat ditentukan oleh fungsi manajemen risiko. Ini sesuai dengan penelitian Filipović, Krišto, dan Podrug (2018) yang menjelaskan pengaruh berbagai situasi krisis terhadap pengembangan manajemen kelangsungan bisnis. Korelasi antara situasi krisis dan pengembangan manajemen kelangsungan bisnis menunjukkan bahwa peningkatan risiko situasi krisis akan meningkatkan tingkat pengembangan manajemen kelangsungan bisnis. Selain itu, risiko strategis dan operasional lebih berpengaruh dalam mengembangkan manajemen kelangsungan bisnis dari bencana alam. Juga, risiko yang tidak diinginkan mempengaruhi pengembangan manajemen kelangsungan bisnis lebih dari risiko yang disengaja. Kontribusi utama dari penelitian ini terletak pada pemodelan pengembangan manajemen kontinuitas bisnis yang terkait dengan berbagai situasi krisis dan kemungkinan terulangnya krisis. Ini menyangkut fungsi manajemen risiko bisnis. Yang penting adalah kebutuhan untuk mengembangkan manajemen kelangsungan bisnis dalam menghadapi ketidakpastian karena gangguan keamanan dan keselamatan proses bisnis.

\section{Implikasi Manajerial untuk Peningkatan Ke- langsungan Bisnis}

Berdasarkan hasil penelitian dan diskusi di atas, penting untuk menggarisbawahi bahwa peningkatan kelangsungan bisnis perusahaan pelayaran sangat penting mengingat bisnis di sektor perkapalan adalah sektor bisnis yang berisiko tinggi. Dengan demikian, upaya untuk meningkatkan kelangsungan bisnis adalah suatu keharusan. Ini konsisten dengan pendapat Kildow (2010) bahwa program keberlanjutan bisnis yang komprehensif yang mencakup semua tautan internal dan eksternal dalam rantai pasokan penting jika bisnis ingin bertahan hidup setelah bencana besar. Dari penelitian yang dilakukan oleh Betty, dapat dikatakan bahwa program kelangsunganbisnis merupakan program penting sehingga perusahaan dapat selamat dari kejadian atau peristiwa yang melanda perusahaan, termasuk jika perusahaan mengalami gangguan keamanan dan keselamatan dalam proses operasi bisnis perusahaan.

Dalam meningkatkan kelangsungan bisnis, prioritas utama adalah Fungsi Manajemen Risiko dengan prioritas 0,39092 adalah kriteria dengan prioritas tertinggi. Kemudian berturut-turut mempertahankan proses bisnis dengan prioritas 0,27899, Paket Dokumentasi 0,18325 dan Pengawasan Manajemen dengan prioritas 0,14684 . Oleh karena itu perusahaan pelayaran perlu didorong untuk meningkatkan fungsi manajemen risiko mereka.
Implikasi manajerial lainnya adalah merujuk pada pendapat Kildow (2010) bahwa bagi karyawan, perusahaan yang memiliki program kelangsunganbisnis yang komprehensif dapat berarti melindungi mata pencaharian dan gaji mereka dengan membantu memastikan bahwa bisnis akan terus berlanjut dan berkembang. Mengabaikan pertimbangan rantai pasokan dalam proses perencanaan kelangsunganbisnis akan menghasilkan rencana yang cenderung gagal saat bencana berikutnya melanda. Dengan demikian kelangsungan bisnis yang dijaga akan memberikan kedamaian bagi karyawan dalam menjalankan perannya di perusahaan dan tentu saja akan berdampak baik bagi perusahaan.

\section{KESIMPULAN}

Kriteria prioritas untuk kelangsungan bisnis pada kontinuitas bisnis, Fungsi Manajemen Risiko dengan prioritas 0,39092 adalah kriteria dengan prioritas tertinggi. Kemudian berturut-turut mempertahankan proses bisnis dengan prioritas 0,27899, Paket Dokumentasi 0,18325 dan Pengawasan Manajemen dengan prioritas 0,14684. Jadi, prioritas tertinggi untuk kelangsungan bisnis industri pelayaran adalah fungsi manajemen risiko. Prioritas prioritas dalam kriteria fungsi manajemen risiko dari yang tertinggi, sebagai berikut: Prioritas Prosedur Pemulihan, Identifikasi Aset \& Gangguan Bisnis, Analisis Perjanjian Bisnis, Identifikasi \& Dokumentasi Aset, Syarat \& Tujuan Pemilihan Bisnis, dan Pemulihan Penting \& Waktu Proses.

\section{Daftar Pustaka}

Allianz Global Corporate \& Specialty, (2018). Safety And Shipping Review 2018.

Andre, K. (2009). The Practitioner's Definition Guide. Safety \& Security. Singapore: Singapore Logistics Association

Annual Report 2018 Piracy and Arm Robbery Against Ship Asia. (2018). Diakses dari www. recaap.org

Bajgoric, N. (2006). Information technologies for business continuity: an implementation framework. Information Management \& Computer Security, 14(5), 450-466.

Bajgoric, N., \& Moon, Y. B. (2009). Enhancing systems integration by incorporating business continuity drivers. Industrial Management \& Data Systems, 109(1), 74-97.

Castillo, C. (2005). Disaster preparedness and business continuity planning at Boeing: An integrated model. Journal of Facilities Management, 3(1), 8-26. 
Filipović, Krišto, dan Podrug (2018). Impact Of Crisis Situations On Development Of Business Continuity Management In Croatia. Journal of Contemporary Management Issues. Vol. 23, 2018, No.1, pp. 99-122

Hecht, J. A. (2002). Business continuity management. Communications of the Association for Information Systems, 8, 444-450.

Kildow, B.A. (2010). The Supply Chain and Business Continuity: Preparing to Survive the Next Disaster. 95th Annual International Supply Management Conference, April 26, 2010

McAfee. (2016). Building and Maintaining a Business Continuity Program. White Paper. Diakses dari www.McAfee.com

Neuman, L. (2011). Social Research Methods: Qualitative and Quantitative Approaches, 7th Edition. USA: Pearson.
Oxford Economics. (2015). The Economic impact of the UK Maritime Services Sector: Shipping. Maritime UK: One voice for shipping, ports and maritime business.

Saaty, T.L., (2005). Theory and Applications of the Analytic Network Process: Decision Making with Benefits, Opprtunities, Costs, and Risks, RWS Publications, Pittsburg, Pennsylvania.

Smith, W. (2016). Shipping Company and The Need for Business Continuity Management. The Navigate Response Newsletter.

Speight, P. (2011). Business continuity. Journal of Applied Security Research, 6(4), 529-554.

Swartz, E., et al. (2003). Greater than the sum of its parts: Business continuity management in the UK finance sector. Risk Management, 5(1), 65-80 